MNT-konferansen 2021 - UiA

\title{
Praksis som læringsform i studier uten profesjonstilknytning - utfordringer og muligheter
}

\author{
Bjørn-Petter Finstad, Ragnhild Sandvoll og Ingrid Hovda Lien, UiT Norges arktiske universitet
}

\begin{abstract}
Hvilke muligheter og utfordringer kan oppstå med praksis som læringsform i utdanninger som ikke er spesifikt profesjonsrettet? I profesjonsutdanninger deler praksisvirksomhetene og utdanningsinstitusjonene ofte en felles forståelse av hva som skal oppnås i praksis, mens i ikkeprofesjonsrettede studieløp er det andre utfordringer. I et nylig oppstartet prosjekt som heter «Samarbeid om praksis i høyere utdanning» har vi som formål å videreutvikle praksisopplegget på det tverrfaglige bachelorprogrammet i fiskeri- og havbruksvitenskap ved Norges fiskerih øgskole, UiT, som har et sterkt innslag av realfag. En særlig utfordring er å utvikle felles læringsmål når studentene er ute i ulike praksisbedrifter. Etter noen år med praksis som et pilotprosjekt, er konklusjonen at praksis er en god læringsform, men at det er behov for utvikling av tydelige læringsutbyttebeskrivelser, nye vurderingsformer, forventningsavklaringer fra alle parter, og veiledning og opplæring for praksisveiledere.
\end{abstract}

\section{INNLEDNING}

Arbeidslivsrelevans og samarbeid med næringslivet er et brennaktuelt tema innen høyere utdanning. I en tid der samfunnet stiller store krav til innovasjon og omstilling, er det viktig at utdanningsinstitusjoner evner å tilby studier som er relevante for arbeidslivet. I denne presentasjonen har vi fokus på muligheter og utfordringer med praksis som læringsform, og med et særskilt søkelys på studieprogrammer som mangler en spesifikk profesjonsorientering.

Bakgrunnen er et nylig oppstartet prosjekt som heter «Samarbeid om praksis i høyere utdanning» ${ }^{1}$, der formålet er å videreutvikle praksisopplegget på det tverrfaglige bachelorprogrammet i fiskeri- og havbruksvitenskap ved Norges fiskerihøgskole, UiT, som har et sterkt innslag av realfag. ${ }^{2}$

Studieprogrammet er ikke profesjonsrettet, men utdanner kandidater til forskjellige stillinger innenfor fiskeri- og havbruksnæringen. I 2015 startet et pilotprosjekt med intensjon om å utvikle et nytt valgemne med praksis. ${ }^{3}$ Fra 2020 er praksisopplegget videreført og blitt en obligatorisk og integrert del av bachelorstudiet i emnet «FSK-2040 Bærekraftig sjømat». I løpet av tre uker i høstsemesteret skal studentene ut i praksis i en virksomhet i sjømatsektoren. Det er inngått avtaler om praksis med store og små produksjonsbedrifter innen fiskeri og havbruk, fiskebåtrederier, interesseorganisasjoner, fiskesalgslag, forvaltningsorganer, forskningsvirksomheter og konsulentselskaper. Selv om vi har høstet mange viktige erfaringer etter innføringen, er vi opptatt av å utvikle praksisopplegget videre i vårt forskningsprosjekt. Hovedproblemstillingen for «Samarbeid om praksis i høyere utdanning» er: Hvordan kan vi oppnå at praksis både skal være relevant, autentisk, bærekraftig og med klare læringsmål for studentene? For å utvikle praksis i det aktuelle studieprogrammet etablerer vi en læringssyklus der studenter, samarbeidspartnere fra arbeids- og næringsliv, undervisere, studieadministratorer og det universitetspedagogiske fagmiljøet samarbeider. Vi skal videre evaluere hvordan praksis fremmer studentenes læring og $\varnothing$ ker deres kompetanse, og ta i bruk formative vurderingsformer for praksis. Et særskilt element er å øke kompetansen hos veiledere i praksisbedriftene, noe som skal oppnås ved at det skal utarbeides et digitalt opplæringsprogram for bedriftene. Dette ivaretas i en arbeidspakke som ledes av representanter for partene i arbeidslivet, LO og NHO. Gjennom å etablere «universitetsbedriften» er hensikten å skape en arena for systematisk flyt av kunnskap, kompetanse og samarbeid mellom akademia og arbeids- og næringslivet.

Med bakgrunn i dette prosjektet vil vi i denne presentasjonen fokusere på hvilke erfaringer som er gjort $\mathrm{i}$ arbeidet med å utvikle praksis som læringsform i denne utdanningen. Problemstillingen som vil 
bli drøftet er: Hvilke muligheter og utfordringer kan oppstå med praksis som læringsform i utdanninger som ikke er spesifikt profesjonsrettet?

\section{PRAKSIS SOM LERINGSFORM}

Praksis som læringsform er velprøvd, særlig innen fagområder som lærerutdanning, ingeniørfag og helseprofesjonsfagene (Brandt 2005). Innen flere profesjonsutdanninger er obligatorisk praksis viktige deler av studieløpet, og det eksisterer gjerne et rammeplanverk som relativt detaljert forteller hva studentene skal ha oppnådd av kunnskaper, ferdigheter og kompetanse etter fullført utdanning. Praksisvirksomheten og utdanningsinstitusjonen har ofte en gjensidig forståelse av dette, og som regel også et felles sett av språk og fagkoder om hva som er viktig. Samtidig er det store variasjoner mellom ulike fag og ulike institusjoner om læringsutbytte av praksis, hvordan praksis skal organiseres og hvilke rolle praksisvirksomheten skal ha mht. ansvar for pedagogisk kvalitet, veiledning og oppfølging (Hegerstrøm 2018). Undersøkelser viser også at mange studenter opplever at det ofte er stor mangel på samsvar mellom uttalte læringsmål og faktisk innhold i mange utdanninger med praksis. Og en vil forvente at utfordringene blir enda større i studier som mangler en klar og tydelig forankret profesjonstilknytning.

Praksis er i dette presenterte prosjektet definert som «planmessig opplæring som foregår i autentiske yrkessituasjoner» (Brandt 2005: 11), og under veiledning av personer med relevant yrkespraksis og kompetanse. Bakgrunnen for at prosjektet har valgt å fokusere på denne læringsformen, er at praksis er blant de minst utviklede læringsformene i bachelorstudiet i fiskeri- og havbruksvitenskap. Andre studentaktive former i programmet er tokt, ekskursjoner, studentpresentasjoner og laboratoriearbeid. Dette er former som har vært utprøvd, utviklet og justert i lang tid, mens praksis er relativt nytt som obligatorisk læringsaktivitet.

I prosjektet har vi særlig fokus på læring av transversale ferdigheter, som også omtales som «transferable skills», «soft skills» eller «21st century skills», og som omfatter kreativitet og innovasjonskompetanse, problemløsning, evne til teamwork og samarbeid, kritisk tenkning, gjennomføringskraft, kommunikasjonskompetanse og profesjonalitet (Cinque 2016). I litteraturen framheves det at slike ferdigheter enklere kan læres i praksisfeltet enn i undervisningsrommet (Shoenfelt et al. 2013; OECD 2018). I vårt prosjekt vil vi utforske hvordan dette kan kombineres. Prosjektet tar utgangspunkt i praksis som grenseobjekt (Star \& Griesemer 1989; Galison 1997) som hverken kan reduseres til et fenomen under full kontroll av undervisningsinstitusjonen eller kun overlates til student og næringslivspartner uten nærmere tilrettelegging. En hovedutfordring er å finne en gunstig mellomposisjon, slik at autentiske yrkessituasjoner og strukturerte læringsformer på universitetet kan styrke hverandre.

\section{EVALUERING OG TILBAKEMELDINGER}

Prosjektet «Samarbeid om praksis i høyere utdanning» startet opp i januar 2021 der kartlegging av erfaringer for videreutvikling inngår. Etter flere års utprøving har vi likevel et visst grunnlag for å peke på noen sentrale utfordringer og muligheter. Dette avsnittet er basert på evalueringene som er gjort som en del av utviklingen av praksisemnet «FSK-2011 Fiskeri og havbruksvitenskap i praksis» etter oppstarten i 2015. Det foreligger evalueringer både fra studentene som har vært ute i praksis, fra bedriftene som har tatt imot studentene og fra dem som er ansvarlige for utvikling og gjennomføringen av emnet ved NFH. Studentene og aktørene fra nærings- og arbeidslivet har svart på nettskjemaer, mens evalueringen fra de involverte ved NFH er basert på en omfattende evalueringsrapport skrevet etter første gang emnet ble gjennomført. I tillegg er diskusjoner og refleksjoner fra de både faglige og administrativt ansatte inkludert. 
Prosjektgruppen for utvikling og etablering av emnet konkluderer i sin evalueringsrapport fra 2016 at det var behov for videreutvikling av emnet både med tanke på formulering av tydelige læringsutbyttebeskrivelser (LUB'er), vurderingsformer, involvering av det øvrige fagmiljøet, kontakten med næringen og ulike overordnete områder som forsikring, boforhold for studentene og kriseplan dersom en eller flere studenter av ulike grunner ikke får gjennomført studiet. Det fremkommer at det allerede ved oppstart var mange bedrifter (40 stykker) som sa seg villige til å ta imot studenter. Videre vises det til at det var 17 av 35 studenter som valgte å ta dette valgemnet det første året, og de ble fordelt på 14 bedrifter. Studentene vektlegger i sin evaluering at de:

- har fått innsikt i hva de ulike bedriftene faktisk gjør

- forstår de ulike leddene i en bedriftene

- lærte om hele næringskjeden i oppdrettsnæringa

- har fått kjennskap/testet forventninger fra bedrifter til sine ansatte

- har fått praktiske ferdigheter med håndtering av levende fisk

I rapporten vises det blant annet til at for noen bedrifter som ikke hadde erfaring med praksis fra tidligere, var det til dels krevende å fylle tre arbeidsuker med meningsfylt innhold. Flere understreket behovet for en klarere bestilling av hva NFH ønsker å oppnå med praksisemnet, det vil si hva studentene skal lære i emnet. Både studenter og bedrifter pekte på behovet for ytterligere klargjøring av formålet med praksis, særlig etterlyser de en konkretisering for bedriftene om hva som er forventet av dem. Det kom også inn forslag til mindre justeringer av mer praktisk art. Prosjektgruppen viser videre til at det i utviklingen av emnet har vært nedsatt en referansegruppe sammensatt av næringslivsaktører, studenter og sentrale personer i fagmiljøet ved NFH. Denne referansegruppen har vært sentral i etableringen og utviklingen av emnet, og deres innspill har hatt stor betydning for den videre utformingen av praksisopplegget.

Evalueringene fra studentene viser at de gjennomgående er veldig godt fornøyd med praksisemnet. Som en av studentene skriver: «praksis er fantastisk og gull verdt», mens en annen svarer dette vedrørende eksempler på gode læringsopplevelser: «praksisemnet og ulike tokt». De fleste studentene viser til at de har fått god kjennskap til bedriften der de har vært utplasserte og de har fătt kunnskap om sjømatssektorens verdikjede. Noen peker imidlertid på at bedriftene burde ha fătt mer informasjon om læringsutbyttet som er skissert for emnet. Videre er det flere som sier at til tross for at de er positive til selve praksisemnet, så ble forventningene til praksis ikke innfridd. En forklaring på dette kan være at det er knyttet store forventinger til praksis og til bedriftene fra studentenes side. En og annen student synes også å ha dårlige erfaringer fra praksisoppholdet, blant annet så vises til at bedriften ikke var tilstrekkelig forberedt på at studenten skulle være i praksis, og at praksisbedriften ikke helt visste hva studentens oppgaver skulle være.

Bedriftene er også gjennomgående fornøyde med å ha studenter i praksis. En næringslivsaktør skriver: «studenter i praksis hos oss har vært en vinn-vinn situasjon for oss og for studenten/UiT». En annen peker på at: «selv om ordningen krever tilrettelegging og en del ressursbruk fra vår side, opplever vi at dette er både nyttig og lærerikt også for oss». En annen sier at dette «er en god rekrutteringsarena for oss».

Men praksisbedriftene peker også på noen utfordringer. Noen av dem er det vanskelig å gjøre noe med, slik som tilgang på råstoff $\mathrm{i}$ de ukene $\mathrm{i}$ høstsemesteret da studentene er i praksis. I

fiskerinæringen er det høyest aktivitet $\mathrm{i}$ vårsemesteret på grunn av sesonginnsigene av fisk, mens det er roligere på høsten. Men lite tilgang på fisk gir lav aktivitet i mange av praksisbedriftene, noe som igjen gjør det utfordrende å legge til rette for relevante og interessante oppgaver for studenten. Også værforholdene kan ha betydning for planlagte aktiviteter i praksis. Når det gjelder forhold som kan forbedres, så viser noen bedrifter til at de ønsker mer informasjon om helheten i studiet, samt informasjon om LUB'ene for selve praksisemnet. Dette er i tråd med hva enkelte studenter også har pekt på, noe som understreker viktigheten av avklaringer av forventninger i forkant av praksis. 
Alle evalueringene har ifølge de faglige ansatte vært vurdert og diskutert, og emnet har vært i kontinuerlig utvikling siden oppstarten i 2015. Når det gjelder mulighetene som ligger i læring i praksis synes de fleste studentene og flertallet av bedriftene at de har hatt «svært godt utbytte» eller «godt utbytte» av ordningen. En gjennomgående tilbakemelding fra både studenter og bedrifter har imidlertid vært betydningen avklaringer av forventninger i forkant av praksisperioden. Evalueringene har gitt vesentlige innspill for den videre kvalitetsutvikling av praksis.

\section{DISKUSJON OG AVSLUTNING}

Sammenlignet med andre læringsformer har praksis en «added value», ved at studentene blir satt i kontakt med autentiske situasjoner i yrkeslivet, noe som gir gode muligheter for et godt læringsutbytte. Vårt praksisprosjekt ligger innenfor de ikke-profesjonsrettede utdanningene der tverrfaglighet, mangfold og variasjon er viktig, men dette gjør det samtidig også særlig utfordrende. Et kjernespørsmål er: Hvordan kan en sikre en felles forståelse av hva slags utbytte studentene skal ha i praksis, når det er så store variasjoner mellom de ulike praksisstedene?

Vi startet praksisemnet i 2015 med et $\varnothing n s k e$ og en intensjon om at praksis ville styrke relevans og studentenes forståelse av egen utdanning. Studentene skal ut i ulike praksisbedrifter fra fiskeri, forvaltning, oppdrett, forskning og organisasjoner i tre uker, og mellom de tre praksisukene har vi koblet det hele sammen med plenumsundervisning og seminarer. Praksisopplegget starter med en simulering av en reell jobbsøkersituasjon, der studentene får presentert utlysninger på stillinger fra praksisbedriftene, og skriver deretter søknad og CV som legges til grunn for fordelingen av de 40-45 studentene mellom de ulike bedriftene.

Da emnet startet opp i 2015, ble det utviklet en læringsutbyttebeskrivelse der store deler av kunnskapsmålene skulle læres i undervisningsrommet, mens ferdigheter og kompetanse skulle læres i løpet av praksisukene. Vi hadde med andre ord en slags arbeidsdeling mellom teoretisk undervisning og praksis, og der vi mellom praksisukene samlet trådene og satt erfaringene fra praksis inn i en større helhet. Dette har fungert godt, men det gjenstår fremdeles flere utfordringer.

Funnene fra evalueringene viser for det første at har vært stor variasjon i opplegg og oppfølging fra praksisbedrift til praksisbedrift, noe som har medført at studentene har fått ulikt utbytte avhengig av kvalitet, prioriteringer, ressurser og tidsbruk hos bedriftene. Studenter vil alltid oppleve variasjoner, men utfordringen blir enda større når en viktig del av læringen foregår på arenaer der de fagansatte på studiet ikke selv er delaktige eller har full kontroll på læringsaktivitetene. Det å bygge bro mellom bedrift og akademia uten at det går på bekostning av autensitet i bedriftene eller på faglig kvalitet, er dermed en av utfordringene. For det andre har det vært sprik i synet på hva utbyttet av praksis egentlig skal være, og hvordan dette skal måles til eksamen. Selv om mange studenter har hatt innholdsrike praksisopphold med karrierefremmende utbytte, er det også enkelte eksempler på skuffelser og kritikk, ikke minst fordi noen av praksisbedriftene ikke har hatt mulighet til tilstrekkelig oppfølging av studentene mens de er i praksis. Det å unngå at læringsutbyttet til studentene varierer med bedriftens ressurser til oppfølging og veiledning, er en utfordring som vil bli viktig å ta tak i den videre utviklingen av praksisopplegget.

Hva kan en forvente av praksis? Det å ha en god forventningsavklaring både på hva vi forventer av praksisbedriftene, hva studentene forventer av praksis og hva vi som utdanningsinstitusjon ønsker skal oppnås, er viktig. Etter oppstarten av praksisemnet i 2015 var dette trukket fram som en særskilt utfordring i evalueringene. For å imøtekomme dette, har vi blant annet jobbet mye med å få praksisbedriftene til å beskrive arbeidsoppgavene studentene skal utføre i praksis så konkret som mulig. Vi har også tematisert forventningsavklaring med studentene før første praksisuke, både i individuelt arbeid og i grupper. I tillegg har våre samarbeidspartnere fra LO og NHO gitt studentene en grundig innføring i hva som er forventninger, krav og rettigheter i arbeidslivet. 
En annen viktig avklaring av hva som er forventet gjelder utbyttet av læring av henholdsvis praksis i bedriftene og i undervisningsrommet på fiskerihøgskolen. Et kjernespørsmål er hvordan disse to arenaene kan forenes på måter som ivaretar både bedriftens autensitet og fagmiljøets ambisjon om å oppnå spesifikke læringsmål gjennom teoretisk undervisning.

Det at studentene er i praksis i mange ulike virksomheter er spennende og gir rom for mange gode diskusjoner og erfaringsutveksling. Samtidig er det krevende å sikre at alle skal kunne vurderes på lik linje i forbindelse med arbeidskrav og eksamen. Vi har derfor valgt å ha samme kunnskapsmål i emnet som kan være relevante for samtlige virksomheter og på tvers av praksiserfaringer. De første årene var overbygningen et felles verdikjedeperspektiv, for å belyse at alle praksisplassene hadde sin plass i sjømatnæringens verdikjede. Imidlertid viste det seg at verdikjedeperspektivet passet best som referanseramme til tradisjonelle produksjonsbedrifter, og var mindre egnet som fellesnevner for andre typer av praksisbedrifter. For studenter som for eksempel var i praksis innen konsulentvirksomhet, forskningsinstitusjoner og interesseorganisasjoner var verdikjedeperspektivet ikke så lett forståelig.

Et forsøk på løse dette er at vi har innført bærekraft som et felles kunnskapsmål. Gjennom undervisningen får studentene kunnskaper om hva en bærekraftanalyse er, og hvordan en slik analyse kan gjennomføres. Siden skal dette settes ut i livet i praksisbedriftene, ved at studentene utforsker hvordan den enkelte praksisbedrift arbeider med bærekraft. Bærekraft er for $\emptyset$ vrig noe som er sentralt gjennom hele bachelorstudiet i fiskeri- og havbruksvitenskap og et svært viktig område for våre praksissamarbeidspartnere.

For å oppsummere: Tilbakemeldingene fra praksisbedriftene er udelt positive. Mange aktører trekker frem at det å ha en student i praksis tilfører dem ny kompetanse og et eksternt blikk på egen virksomhet. Studentene opplever å bli verdsatt, og mange gir også tilbakemelding om at de nå ser en større relevans i emnene de har tatt tidligere i bachelorgraden. Dessuten åpner det seg muligheter for jobb, mastergradsoppgaver og lignende i samarbeid med praksisbedriftene (Meld. St. 16 (2016-2017), Kultur for kvalitet i høyere utdanning, s. 61). De faglige ansvarlige har gjennom tett kontakt med både sjønæringen og studentene utviklet praksis som læringsform, men for videre styrking av kvaliteten synes det fortsatt viktig å fokusere på forventningsavklaringer i forkant av praksisperiodene, mer informasjon til bedriftene vedrørende læringsutbytte for studentene samt å fokusere på den veiledningen som skjer i praksis. Dette vil være sentralt for videre utforskning i prosjektet.

Avslutningsvis vil vi påpeke at en ambisjon i prosjektet er at resultatene vil ha betydelig overføringsverdi til andre studieprogrammer innen høyere utdanning, og særlig til tverrfaglige studier uten en klar og tydelig profesjonstilknytning.

\footnotetext{
${ }^{1}$ Diku-prosjekt ARB-2020-10088, prosjektperiode fra januar 2021 til desember 2023.

${ }^{2}$ Bachelorstudiet i fiskeri- og havbruksvitenskap består av matematikk, kjemi, fiskeribiologi, redskapsteknologi, jus, strategi, marked, sjømatproduksjon, fiskeri- og havbruksforvaltning og praksis.

${ }^{3}$ Omtalt i: Meld. St. 16 (2016-2017) Kultur for kvalitet i høyere utdanning, s. 61.
}

\section{REFERANSER}

Brandt, E. (2005). Kartlegging av praksisbasert høyere utdanning. NIFU STEP Skriftserie, NIFU STEP.

Cinque, M. (2016). "Lost in translation”. Soft skills development in European countries. Tuning Journal for Higher Education, Vol. 3, Issue No. 2, pp. 389-427

Evalueringer fra 2015 til 2020 ved Norges Fiskerihøyskole, BFE, UiT Norges Arktiske Universitetet.

Galison, P. (1997). Image and logic: A material culture of microphysics, The University of Chicago Press.

Hegerstrøm, T. (2018). Til glede og besvær - praksis i høyere utdanning. NOKUTs utredninger og analyser. 
Meld. St. 16 (2016-2017) Kultur for kvalitet i høyere utdanning.

OECD (2018). In-depth analysis of the labour market relevance and outcomes of higher education systems: Norway, OECD.

Shoenfelt, E. L., et al. (2013). Internships: An established mechanism for increasing employability. Industrial and Organizational Psychology, Vol. 6, No. 1.

Star, S. L. and J. Griesemer (1989). Institutional Ecology, "Translations” and Boundary Objects: Amateurs and Professionals in Berkeley's Museum of Vertebrate Zoology 1907-39, Social Studies of Science, Vol. 19, No. 3, pp. 387-420.

Science, Vol. 19, No. 3, pp. 387-420. 